\title{
Trace metal speciation at the sediment-water interface of Vidy Bay: influence of contrasting sediment characteristics
}

\author{
Matthieu Masson · Mary-Lou Tercier-Waeber
}

Received: 15 January 2013/ Accepted: 17 October 2013/Published online: 5 November 2013

(C) Springer Basel 2013

\begin{abstract}
Trace metal analysis and speciation were performed at the sediment-water interface of Vidy Bay (Lake Geneva, Switzerland). This bay is impacted by hazardous compounds released via the sewage effluent of a major wastewater treatment plant (WWTP). Sediment cores and overlying water were sampled simultaneously at 12 sites characterized by contrasting sediment surface characteristics (color, methanogenic activity, bacterial mat) using corers deployed from a MIR submarine or research boat. The concentrations of trace metals in particulate form in the sediment and dissolved in the interstitial water, as well as the particulate, colloidal and dynamic fractions of trace metals in the overlying water were determined by combining an in situ and laboratory multi-method analytical approach. The results indicate differences in trace metal speciation in the sediment and overlying water at the 12 investigated sites. The observed differences were found to be more correlated to bacterial community, abundance, type and activity than to distance from the WWTP sewage outlet.
\end{abstract}

Keywords Metal speciation - Sediment . Interstitial water - Overlying water - Bacterial mat . Methanogenesis

This article is part of the special issue "éLEMO - investigations using MIR submersibles in Lake Geneva".

M. Masson · M.-L. Tercier-Waeber ( $\square)$

Analytical and Environmental Chemistry, Department of Inorganic and Analytical Chemistry, Faculty of Sciences, University of Geneva, Sciences II, 30 Quai E-Ansermet, 1211 Geneva, Switzerland

e-mail: Marie-Louise.Tercier@unige.ch

\section{Introduction}

Vidy Bay, located on the northern shore of Lake Geneva (Fig. 1a), is a sensitive area. It is located $<4 \mathrm{~km}$ from the pumping station of St. Sulpice that provides $<60 \%$ of the drinking water for the inhabitants of the municipality of Lausanne (Fig. 1a). It is the most polluted area of the lake (e.g. Loizeau et al. 2004; Pardos et al. 2004). The main source of pollution is the effluent of the waste-water treatment plant (WWTP) of Lausanne that is released, via a pipe, directly into the bay since 1964. In an attempt to reduce the contamination impact of the WWTP, the sewage effluent pipe outlet, originally located at a depth of $12 \mathrm{~m}$ and a distance of $350 \mathrm{~m}$ from the shore, was moved in 2004 to a depth of $35 \mathrm{~m}$ and to a distance of $700 \mathrm{~m}$ from the shore. The study by Pote et al. (2008) showed that the effect of the elongation of the WWTP pipe on contamination of the sediments by hazardous compounds carried by the WWTP sewage effluent, and trace metals in particular was only partially successful.

Metals transported to the sediment can be either buried or remobilized (Van Den Berg et al. 1999) via various diagenetic processes, e.g.: bacterially mediated oxidation of organic matter inducing redox reactions such as oxygen consumption near the water-sediment interface and reduction of nitrate, manganese oxides, iron oxides and sulfate (Froelich et al. 1979). These dynamic redox processes affect metal equilibrium between the solid and liquid phases (via precipitation, adsorption/desorption, sulfide complexation, organic ligand biological degradation, and/or biological uptake processes) and therefore their speciation and rates of transfer across the sediment-water interface. Understanding the role of sediments as either a sink or source of trace metals released by the WWTP sewage effluent in the bay is thus of prime interest for assessment of their long-term impact. For this purpose, investigations based only on the measurements of the total 
Fig. 1 a Map of the study area, Vidy Bay (Switzerland). Squares on the map (numbered from A to $L$ ) represent the localization of the 12 study sites. The white arrow represents the location of the WWTP pipe end. The black arrow gives the rough location of the pumping station pipe end (1 km from the shore; $50 \mathrm{~m}$ depth). The star represents the reference SLH2 station located at the deepest part of the lake, almost halfway between the French and Swiss coastlines. b Photos of (b1) the MIR submarine equipped with the VIP system; b2 the rosette supporting the corers during the MIR dives; core sampling in sediment characterized by the presence of (b3) large white filament-like bacterial mat (e.g. sites $\mathrm{D}, \mathrm{I}, \mathrm{J}$ and $\mathrm{K})$; b4 high methanogenic activity (e.g. sites A, B, I and J), and b5 pillow structure (site $\mathrm{H}$ )

\section{a}

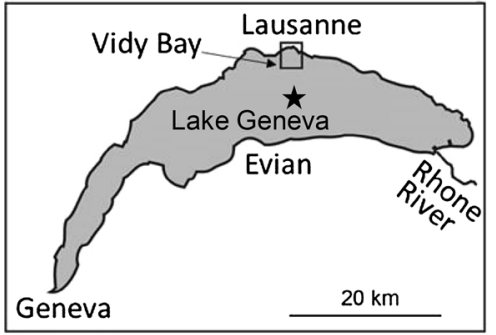$$
1
$$
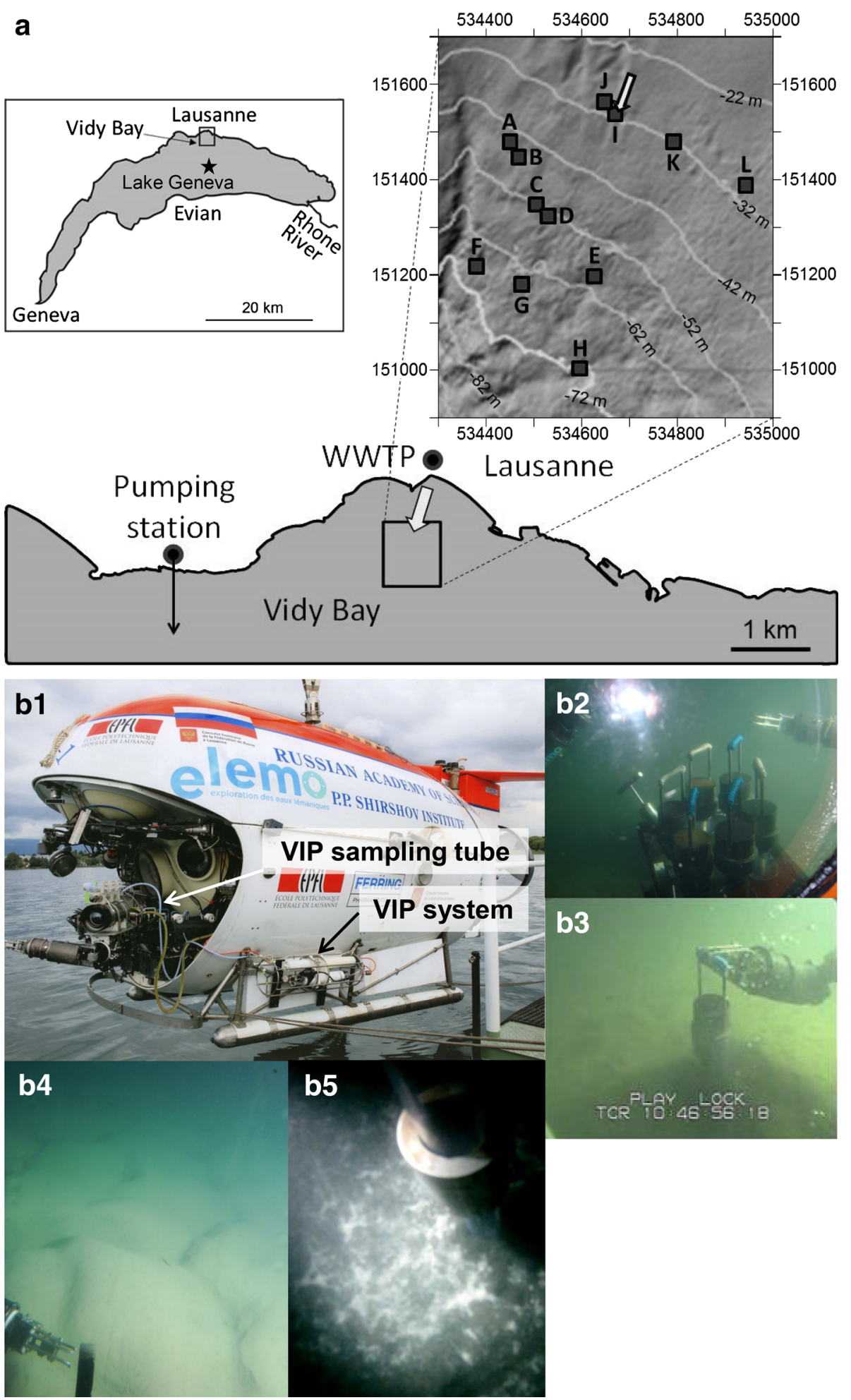

concentration of metals in the particulate form in the sediment, as performed in all previous studies related to trace metals in the bay (e.g. Arbouille et al. 1989; Monna et al. 1999; Loizeau et al. 2004; Pardos et al. 2004; Poté et al. 2008; Thevenon et al. 2011), are insufficient. Detailed studies of trace metal speciation at the sediment-water interface as a function of biogeochemical conditions are required.

The aim of this work, as part of the éLEMO project (Wüest et al. 2013), was a first step toward such a study. It focused on assessing the influence of sediment characteristics (color, 
morphology, methanogenic activity, bacterial mat) on the speciation of trace metals at the sediment-water interface. To achieve this, the "MIR" submarines (Shirshov Institute of Oceanology, USSR Academy of Sciences) and the research boat "La Licorne" (Institute F.-A. Forel, University of Geneva) were used to (1) map the spatial sediment characteristics in a defined geographic area surrounding the WWTP pipe outlet; (2) perform in situ and on-board measurements, respectively, of metal fraction available for bio-uptake; and (3) collect sediment and overlying waters at contrasting sites for complementary analysis of i) particulate and dissolved metal concentrations in the sediment and overlying water; and ii) sediment interstitial and overlying water composition.

\section{Methodology}

Field sample collection and measurements

Sampling was performed at 12 sites in Vidy Bay (Fig. 1a): 8 sites (samples A-H) during the MIR dives in July 2011 and 4 sites (samples I-L) during a complementary survey in May 2012 with the research boat "La Licorne" (Institute F.-A. Forel, University of Geneva). These sites, selected from video recordings made during preliminary studies with the MIR submarines and "La Licorne", were characterized by contrasting sediment surface color, morphology, methanogenic activity and bacterial mat (Table 1; Fig. 1b). At each site, sediment and overlying water were collected simultaneously using Plexiglas corers $(5.7 \mathrm{~cm}$ in diameter and $\sim 60 \mathrm{~cm}$ length). These devices were manipulated by the arm of the MIR submarine during each dive (Fig. 1b2, b4) or were sunk by gravity when deployed from the boat (Fig. 1b3). The cores were hermetically sealed as soon after their retrieval on board to prevent $\mathrm{O}_{2}$ penetration and were rapidly transported to the laboratory for specific sampling in a glove box under $\mathrm{N}_{2}$ atmosphere.

The overlying water was first sampled using washed PP syringes and tygon tubes. An aliquot of raw water was collected and acidified to $\mathrm{pH} 1$ with $\mathrm{HNO}_{3}$ suprapur for the analysis of the total acid extractable particulate metal $\left(\mathrm{Me}_{\mathrm{T}}\right)$ concentrations at $\mathrm{pH} 1$. A second aliquot was filtered through $0.45 \mu \mathrm{m}$ pore size acetate cellulose membranes (Whatman) and acidified with $\mathrm{HNO}_{3}$ (suprapur $14 \mathrm{M}$, $1 \% \mathrm{v} / \mathrm{v})$ for total dissolved metal $\left(\mathrm{Me}_{\mathrm{D}}\right)$ analysis. The upper part of the sediment was then sliced into three layers $(0-1.5,1.5-3$ and $3-6 \mathrm{~cm})$ with plastic cutters. The outer part of the sediment core in contact with the side of the corer was discarded. Each sediment slice was placed into $50 \mathrm{ml} \mathrm{HNO}_{3}$ cleaned PP centrifuge tubes (Greiner(C) and immediately centrifuged at 3,500 rpm for $40 \mathrm{~min}$ to extract pore waters. The pore water samples were filtered in the glove box (under $\mathrm{N}_{2}$-atmosphere) using $0.45 \mu \mathrm{m}$ pore size acetate cellulose membranes (Whatman) and acidified with $\mathrm{HNO}_{3}$ (suprapur $14 \mathrm{M}, 1 \% \mathrm{v} / \mathrm{v}$ ) for total dissolved interstitial metal $\left(\mathrm{Me}_{\mathrm{I}}\right)$ analysis. All samples for measurements of $\mathrm{Me}_{\mathrm{I}}, \mathrm{Me}_{\mathrm{T}}$ and $\mathrm{Me}_{\mathrm{D}}$ were stored at $4{ }^{\circ} \mathrm{C}$ in the dark prior to analysis. Sediments were lyophilized using a CHRIST BETA $1-8 \mathrm{~K}$ freeze-drying unit $\left(-54{ }^{\circ} \mathrm{C}, 6 \mathrm{~Pa}\right)$, and then crushed in an agate mortar. Representative subsamples ( $\sim 30 \mathrm{mg}$ ) of lyophilized, powdered and homogenized sediment were digested in $750 \mathrm{~mL} \mathrm{HCl}$ (12 M suprapur) and $250 \mathrm{~mL} \mathrm{HNO}_{3}$ (14 M suprapur) in closed Teflon

Table 1 Description of the 12 study sites in Vidy Bay

\begin{tabular}{|c|c|c|c|c|c|c|c|c|c|}
\hline \multirow[t]{2}{*}{ Site } & \multicolumn{2}{|c|}{ WGS84 coordinates } & \multicolumn{2}{|c|}{ SWISS coordinates } & \multirow{2}{*}{$\begin{array}{l}\text { Distance from } \\
\text { outlet pipe (m) }\end{array}$} & \multirow[t]{2}{*}{ Depth (m) } & \multicolumn{3}{|c|}{ Sediment observations } \\
\hline & $\begin{array}{l}\text { Latitude } \\
\left({ }^{\circ} \text { decimal }\right)\end{array}$ & $\begin{array}{l}\text { Longitude } \\
\left({ }^{\circ} \text { decimal }\right)\end{array}$ & $X(\mathrm{~m})$ & $Y(\mathrm{~m})$ & & & $\begin{array}{l}\text { Bacterium } \\
\text { mat }\end{array}$ & $\begin{array}{l}\text { Methane } \\
\text { degassing }\end{array}$ & Color \\
\hline A & 46.511417 & 6.584550 & 534,450 & 151,481 & 232 & 42 & $\varnothing$ & $\mathrm{M}+$ & Light brown-small white spots \\
\hline B & 46.511133 & 6.584783 & 534,468 & 151,449 & 226 & 42 & $\mathrm{~B}-$ & $\mathrm{M}+$ & Light brown-small white spots \\
\hline $\mathrm{C}$ & 46.510233 & 6.585267 & 534,504 & 151,349 & 258 & 46 & $\mathrm{~B}-$ & $\mathrm{M}-$ & Light brown-black and white spots \\
\hline $\mathrm{D}$ & 46.510033 & 6.585617 & 534,530 & 151,326 & 261 & 51 & $\mathrm{~B}+$ & $\mathrm{M}-$ & Light brown-black spots \\
\hline $\mathrm{E}$ & 46.508883 & 6.586883 & 534,626 & 151,197 & 350 & 52 & $\varnothing$ & $\varnothing$ & Light brown-black and white spots \\
\hline $\mathrm{F}$ & 46.509050 & 6.583667 & 534,379 & 151,218 & 439 & 61 & $\varnothing$ & $\mathrm{M}-$ & Light brown \\
\hline G & 46.508717 & 6.584933 & 534,476 & 151,180 & 414 & 60 & $\varnothing$ & $\varnothing$ & Light brown \\
\hline $\mathrm{H}$ & 46.507150 & 6.586533 & 534,597 & 151,005 & 544 & 70 & $\varnothing$ & $\varnothing$ & Pillow/trench structures \\
\hline I & 46.511989 & 6.587403 & 534,670 & 151,540 & 5 & 31 & $\mathrm{~B}+$ & $\mathrm{M}+$ & Heterogeneous with wastes \\
\hline $\mathrm{J}$ & 46.512212 & 6.587112 & 534,648 & 151,565 & 33 & 31 & $\mathrm{~B}+$ & $\mathrm{M}+$ & Heterogeneous with wastes \\
\hline K & 46.511462 & 6.589014 & 534,793 & 151,480 & 136 & 32 & $\mathrm{~B}+$ & $\varnothing$ & Heterogeneous with wastes \\
\hline $\mathrm{L}$ & 46.510649 & 6.591007 & 534,945 & 151,388 & 314 & 27 & $\varnothing$ & $\varnothing$ & Light brown \\
\hline
\end{tabular}

For the sediment observations, three qualitative criteria were considered: presence or absence of bacterial mat $(\mathrm{B}+$, large bacterial mat; $\mathrm{B}-$, small bacterial mat; $\varnothing$, absence of bacterial mat), methanogenic activities (M+, gas bubbles observed continuously; $M-$, gas bubbles observed during core sampling; $\varnothing$, absence of bubbles) and color of sediment 
reactors (Savillex $\odot$ ) on a heating plate $\left(2 \mathrm{~h}\right.$ at $\left.110{ }^{\circ} \mathrm{C}\right)$. The Teflon reactors were then opened and heating processes continued until complete evaporation of the reagent solution. The dry residues were re-dissolved in $150 \mathrm{~mL} \mathrm{HNO}_{3}$ (14 M suprapur) at $70{ }^{\circ} \mathrm{C}$ for $15 \mathrm{~min}$. After cooling, final sample volumes were brought to $10 \mathrm{~mL}$ with ultra-pure water (Milli-Q) and stored at $4{ }^{\circ} \mathrm{C}$ in the dark prior to analysis.

A voltammetric in-situ profiling (VIP) system, incorporating a GIME sensor (Tercier-Waeber and Taillefert 2008), was used at each site to perform direct square-wave anodic stripping voltammetric (SWASV) measurements of the concentration of the dynamic fraction of $\mathrm{Cd}, \mathrm{Pb}$ and $\mathrm{Cu}$ $\left(\mathrm{Me}_{\mathrm{dyn}}\right)$ in the overlying water. This fraction, defined as the sum of the concentration of the free metal ion and labile metal complexes with size typically of few nanometers, is relevant in terms of ecotoxicity assessment as it represents the maximum fraction of metal potentially bioavailable (Buffle and Tercier-Waeber 2005). Reliable measurements of this metal fraction using traditional analytical techniques are almost impossible due to sample perturbations that may occur during sampling, sample handling and storage. Sample perturbation includes contamination of trace metals or their losses by adsorption onto the wall of containers, but also for samples collected at depths, speciation changes due to variations in temperature, pressure, $\mathrm{CO}_{2}$ and $\mathrm{O}_{2}$ content and therefore $\mathrm{pH}$ (see Tercier-Waeber and Taillefert 2008; Tercier-Waeber et al., in preparation; for detailed discussion and examples). During the MIR campaign, the VIP system was installed at the side of the MIR submarine, and the end of its sampling tube was fixed to the arm of the submarine (Fig. 1b) to allow in situ Me $\mathrm{dyn}_{\mathrm{n}}$ SWASV measurements in overlying waters sampled at 20 and $40 \mathrm{~cm}$ above the sediments. During the boat survey, on-board $\mathrm{Me}_{\mathrm{dyn}}$ SWASV VIP measurements were performed in an aliquot of the overlying water immediately after sediment core retrieval. SWASV conditions used in both applications were as follows: $E_{\mathrm{dep}}=-1,200 \mathrm{mV} ; t_{\mathrm{dep}}=15-30 \mathrm{~min}$; $E_{\mathrm{f}}=+100 \mathrm{mV} ; f=200 \mathrm{~Hz}$; step amplitude $8 \mathrm{mV}$; pulse amplitude $25 \mathrm{mV}$. Under these conditions, GIME-VIP analytical limits of detection ( $\mathrm{LD}=$ blank $+3 \sigma$ ) were $0.9 \mathrm{ng} \mathrm{L}^{-1}$ for $\mathrm{Cd}, 1.5 \mathrm{ng} \mathrm{L}^{-1}$ for $\mathrm{Pb}$ and $10 \mathrm{ng} \mathrm{L}^{-1}$ for $\mathrm{Cu}$. Relative standard deviation (RSD) of the average of 3 replicate measurements was found to be typically $\leq 12 \%$ for concentrations close to the LD and $\leq 8 \%$ for concentrations 3 times the LD.

Analytical methods for chemical analysis in the laboratory

Concentrations of $\mathrm{Cd}, \mathrm{Pb}, \mathrm{Cu}$ and $\mathrm{Mn}$ in the samples of overlying $\left(\mathrm{Me}_{\mathrm{T}}, \mathrm{Me}_{\mathrm{D}}\right)$ and interstitial $\left(\mathrm{Me}_{\mathrm{I}}\right)$ waters, and the digested sediment samples $\left(\mathrm{Me}_{\mathrm{P}}\right)$ were measured by ICP-
MS (Agilent 7700) using rhodium and rhenium as internal standards. The accuracy of $\mathrm{Cd}, \mathrm{Pb}, \mathrm{Cu}$ and $\mathrm{Mn}$ analyses was, respectively, within $6,3,3$ and $2 \%$ of the certified values of the reference water SLRS- $4(n=16)$ and precision was generally better than, respectively, 7, 7, 5 and $4 \%$ (RSD; $n=16$ ), for concentrations three times higher than detection limits $\left(\mathrm{Cd} 0.7 \mathrm{ng} \mathrm{L}^{-1}, \mathrm{~Pb} 4 \mathrm{ng} \mathrm{L}^{-1}, \mathrm{Cu}\right.$ $6 \mathrm{ng} \mathrm{L}^{-1}$, Mn $\left.40 \mathrm{ng} \mathrm{L}^{-1} ; 3 \sigma\right)$. Concentrations of the various $\mathrm{Fe}$ fractions were measured by GF-AAS (Varian, AA240FS). Accuracy was within $8 \%$ of certified values (SLRS-4) and the analytical error was $<5 \%$ at concentrations levels ten times higher than detection limits (GFAAS $\left.0.5 \mu \mathrm{g} \mathrm{L}^{-1} ; 3 \sigma\right)$. Accuracy of $\mathrm{Cd}_{\mathrm{P}}, \mathrm{Pb}_{\mathrm{P}}, \mathrm{Cu}_{\mathrm{P}}, \mathrm{Mn}_{\mathrm{P}}$ and $\mathrm{Fe}_{\mathrm{P}}$ analyses in certified reference sediment (LKSD-4) digested samples was within $6 \%$ of certified values $(n=8)$ and the analytical error was generally $<6 \%$ (RSD; $n=8$ ) for all analytes at concentration levels ten times higher than detection limits $\left(\mathrm{Cd} \quad 0.02 \mathrm{mg} \mathrm{kg}^{-1}, \mathrm{~Pb}\right.$ $1 \mathrm{mg} \mathrm{kg}^{-1}$, Cu $0.4 \mathrm{mg} \mathrm{kg}^{-1}$, Mn $3 \mathrm{mg} \mathrm{kg}{ }^{-1}$, Fe $0.2 \mathrm{~g} \mathrm{~kg}^{-1}$; $3 \sigma$ estimated from blank analyses and for a nominal sample weight of $30 \mathrm{mg}$ of sediment; $n=8$ ). POC contents were determined using a CHN analyzer (CHNEA110, CE Instruments Ltd) after carbonate fumigation exposing the particle samples to concentrated $\mathrm{HCl}$ vapors for $6 \mathrm{~h}$ (Harris et al. 2001).

\section{Results and discussion}

Particulate trace metal concentrations in sediments

Concentrations of metals in particulate form $\left(\mathrm{Me}_{\mathrm{P}}\right)$ in the 3 layers $(0-1.5,1.5-3$ and $3-6 \mathrm{~cm})$ of the sediment are reported in Table 2 for the 12 sites. $\mathrm{Cd}_{\mathrm{P}}, \mathrm{Pb}_{\mathrm{P}}$ and $\mathrm{Cu}_{\mathrm{P}}$ concentrations between sites varied in the range 0.86-13.2, 47.6-491 and 92.8-352 mg kg${ }^{-1}$, respectively. $\mathrm{Me}_{\mathrm{P}}$ concentrations in the three layers at a given site varied by a factor of 1-2 (Table 2). No systematic variation of $\mathrm{Me}_{\mathrm{P}}$ concentrations was observed as a function of sediment depth. To compare $\mathrm{Me}_{\mathrm{P}}$ concentration levels between the different sites, mean concentrations of the three layers $(0-6 \mathrm{~cm})$ were calculated (Fig. 2a). At all sites, mean $\mathrm{Cd}_{\mathrm{P}}$, $\mathrm{Pb}_{\mathrm{P}}$ and $\mathrm{Cu}_{\mathrm{P}}$ concentrations were higher than the $\mathrm{Me}_{\mathrm{P}}$ background concentration level (Arbouille et al. 1989; Cd $0.2 \mathrm{mg} \mathrm{kg}^{-1}, \mathrm{~Pb} 30 \mathrm{mg} \mathrm{kg}^{-1}, \mathrm{Cu} 30 \mathrm{mg} \mathrm{kg}^{-1}$ ) measured in a core collected in the reference station SLH2 in the deepest part of the lake (Fig. 1). Enrichment factors were typically in the range of 5-50, 2-13 and 4-10, for $\mathrm{Cd}, \mathrm{Pb}$ and $\mathrm{Cu}$, respectively. The $\mathrm{Me}_{\mathrm{P}}$ monitored concentrations were compared with threshold effect concentrations (TEC, MacDonald et al. 2000; Cd $0.99 \mathrm{mg} \mathrm{kg}^{-1}, \mathrm{~Pb}$ $35.8 \mathrm{mg} \mathrm{kg}^{-1}, \mathrm{Cu} 31.6 \mathrm{mg} \mathrm{kg}^{-1}$ ) and the probable effect concentration (PEC, MacDonald et al. 2000; Cd 
$4.98 \mathrm{mg} \mathrm{kg}^{-1}, \mathrm{~Pb} 128 \mathrm{mg} \mathrm{kg}^{-1}, \mathrm{Cu} 149 \mathrm{mg} \mathrm{kg}^{-1}$ ). For concentrations under the TEC level, toxicity to benthicdwelling organisms are predicted to be unlikely. For concentrations above the PEC level, toxicity is probable. Between TEC and PEC levels, toxic effects may depend on the type of organism. All $\mathrm{Pb}_{\mathrm{P}}$ and $\mathrm{Cu}_{\mathrm{P}}$ concentrations and $80 \%$ of the $\mathrm{Cd}_{\mathrm{P}}$ concentrations exceeded the TEC. $\mathrm{Cu}_{\mathrm{P}}$ concentrations measured at 8 of the 12 sites were higher than the PEC, while higher $\mathrm{Cd}_{\mathrm{P}}$ and $\mathrm{Pb}_{\mathrm{P}}$ concentrations compared to PEC were measured only at site $\mathrm{D}$ and at sites A and D, respectively (Fig. 2a). These results confirm that surface sediments of Vidy Bay are contaminated by the three metals with, for $\mathrm{Cu}$, a probable toxic effect for the biota. $\mathrm{Me}_{\mathrm{P}}$ concentrations measured in this study (2011-2012) were, respectively, similar and lower compared to those reported for the years 2005 and 1996; i.e. after and prior the elongation of the WWTP pipe (Poté et al. 2008). This confirms that elongation of the WWTP pipe outlet in an attempt to decrease the impact of metals released by the sewage effluent on sediment quality, i.e. via an increase in their dilution, has been only partially successful. It also suggests that the amounts of metals not retained during the cleaning treatment cycles are at similar level over at least the last decade.

Mean $\mathrm{Me}_{\mathrm{p}}$ concentrations measured at site $\mathrm{D}$ were superior to those measured at the other sites (Fig. 2a). Site $\mathrm{D}$ also was characterized by a high POC concentration (Table 2), the presence of white filament-like bacteria at the sediment surface (Table 1) and important communities of Beggiatoa sp. and endospore-forming bacterium Clostridium spp. (Sauvain et al. 2013). The latter ( $\sim 50 \%$ of the total bacterial community; Sauvain et al. 2013) are found in human feces. These results suggest that metals, POC and endospore-forming bacteria observed at site D derive most probably from the WWTP effluent and were co-transported from the outlet pipe to this particular site. Site D is located in a south-west direction from the outlet pipe where an oblate distribution pattern of trace metal in the sediment was observed by Pardos et al. (2004) before the extension of the pipe in 2001. Considering a sedimentation rate of 1-2 $\mathrm{cm}^{\text {year }}{ }^{-1}$ in this area (Loizeau et al. 2003), the high $\mathrm{Me}_{\mathrm{P}}$ concentrations at site $\mathrm{D}$ are unlikely due to metal accumulation prior to 2001 (i.e. prior to extending the pipe). This suggests that a south-west distribution pattern of the metals in the sediment may still be important. This hypothesis is supported by the results of the 3D seasonal monitoring of the WWTP effluent spreading in the water column of Vidy Bay obtained in a recent study that showed a complex spreading pattern of the effluent, although either in a south-west or south-east direction depending on the wind regime (Masson et al., in preparation). These latest results explain not only the high $\mathrm{Cd}_{\mathrm{p}}$ and $\mathrm{Pb}_{\mathrm{p}}$ concentrations observed at sites $\mathrm{A}, \mathrm{B}, \mathrm{C}, \mathrm{D}$ and $\mathrm{F}$ but also at site L (Figs. 1, 2a). They also support the hypothesis that $\mathrm{Cd}$ and $\mathrm{Pb}$ are mainly issued from the WWTP effluent. The trend in $\mathrm{Cu}_{\mathrm{p}}$ concentration distribution appeared slightly different from those of the two other metals, with high $\mathrm{Cu}_{\mathrm{p}}$ concentrations measured also at sites $\mathrm{I}, \mathrm{J}$ and $\mathrm{K}$ (Fig. 2a). This suggests an additional diffuse source of $\mathrm{Cu}_{\mathrm{p}}$ in the coastal area, possibly from the Chambronne River (another source of water in the bay), in which the watershed drains agricultural regions, including vineyards. This river is also suspected to be the source of some pesticides detected in the bay (Bonvin et al. 2011). $\mathrm{Me}_{\mathrm{P}}$ concentrations measured at site $\mathrm{D}$ in particular, but also at sites A, B, C, F and L (Fig. 2a), show that the spatial distribution of metal concentrations in the sediments of Vidy Bay is not clearly concentric from the outlet pipe of the WWTP discharge as suggested by Poté et al. (2008) and suggests that the impact of the WWTP effluent is highly variable in space and time (see Goldscheider et al. 2007).

Trace metal in the interstitial water of the sediment

Dissolved $\mathrm{Cd}, \mathrm{Pb}$ and $\mathrm{Cu}$ concentrations measured in the interstitial water $\left(\mathrm{Me}_{\mathrm{I}}\right)$ of the 3 layers of sediment $(0-1.5$, $1.5-3$ and $3-6 \mathrm{~cm})$ and at the 12 sites varied between 2.8 and 368, 45 and 9,620, 261 and 21,000 $\mathrm{ng} \mathrm{L}^{-1}$, respectively (Table 2). $\mathrm{Me}_{\mathrm{I}}$ concentrations were generally higher in the deepest layer $(3-6 \mathrm{~cm})$ than the two surface layers $(0-1.5$ and $1.5-3 \mathrm{~cm})$, suggesting differences in bacterial abundance, activities and type, or redox conditions at the three depths. High-resolution profiles of master bio-physicochemical conditions would be required for a more detailed interpretation of the change in metal concentrations monitored in the three layers. As such data are not available at the present state of this work, mean concentrations of the three layers also were compared between sites (Fig. 2b). Mean $\mathrm{Cd}_{\mathrm{I}}, \mathrm{Pb}_{\mathrm{I}}$ and $\mathrm{Cu}_{\mathrm{I}}$ concentrations were clearly higher at site $\mathrm{D}$ and at the three closest sites of the pipe outlet, i.e. sites I, J and $\mathrm{K}\left(\mathrm{Cd}_{\mathrm{I}} 39-180 \mathrm{ng} \mathrm{L}^{-1} ; \mathrm{Pb}_{\mathrm{I}}\right.$ $\left.1,100-4,300 \mathrm{ng} \mathrm{L}^{-1} ; \mathrm{Cu}_{\mathrm{I}} 3,970-12,800 \mathrm{ng} \mathrm{L}^{-1}\right)$ compared to those of the other sites (6.3-21, 80-814 and 461-1,560 $\mathrm{n} \mathrm{L} \mathrm{L}^{-1}$, respectively). These four sites are characterized by the presence of large white filament-like bacterial mats (Table 1) as well as high POC concentrations at sites D and I (Table 2). Therefore, the increase in $\mathrm{Me}_{\mathrm{I}}$ for the three target metals is highly suspected to be related to bacterial activity. At sites $\mathrm{I}$, $\mathrm{J}$, and $\mathrm{K}$, mean $\mathrm{Fe}_{\mathrm{I}}$ and $\mathrm{Mn}_{\mathrm{I}}$ concentrations measured $(2,760-6,300$ and $70-120 \mu \mathrm{g} \mathrm{L}^{-1}$, respectively) were also significantly higher than those measured at the other sites $(303-3,060$ and 22-96 $\mu \mathrm{g} \mathrm{L}^{-1}$, respectively; Table 2). These high $\mathrm{Fe}_{\mathrm{I}}$ and $\mathrm{Mn}_{\mathrm{I}}$ concentrations highlight a strong reduction of $\mathrm{Fe}$ and $\mathrm{Mn}$ oxides induced by the important, highly diverse bacterial communities specific to sites I, J and K; i.e. those 
closest to the outlet pipe (Sauvain et al. 2013). Similar observations were reported by Haller et al. (2011) in the same area. Bacterial mineralization of organic matter and reduction of $\mathrm{Fe}$ and $\mathrm{Mn}$ oxides, which are known to be sorbents of choice for the target metals (Dong et al. 2007), may explain the high $\mathrm{Cd}_{\mathrm{I}}, \mathrm{Pb}_{\mathrm{I}}$ and $\mathrm{Cu}_{\mathrm{I}}$ concentrations measured at sites I, J and K (Fig. 2b). The role of bacterial activity on $\mathrm{Fe}$ and $\mathrm{Mn}$ reduction at sites $\mathrm{I}, \mathrm{J}$ and $\mathrm{K}$ is also supported by the fact that at sites where no bacterial mats were observed, $\mathrm{Fe}_{\mathrm{I}}$ and $\mathrm{Mn}_{\mathrm{I}}$ concentrations were very low while $\mathrm{Fe}_{\mathrm{P}}$ and $\mathrm{Mn}_{\mathrm{P}}$ concentrations at all sites were similar (Tables 1, 2). In contrast, at site $\mathrm{D}$, also characterized by high $\mathrm{Me}_{\mathrm{I}}$ concentrations of the three target metals (Fig. 2b) and the presence of bacteria (Table 1), $\mathrm{Fe}_{\mathrm{I}}$ and $\mathrm{Mn}_{\mathrm{I}}$ concentrations were low (Table 2). The low $\mathrm{Fe}_{\mathrm{I}}$ and $\mathrm{Mn}_{\mathrm{I}}$ concentrations can be explained by the fact that Beggiatoa sp. and Clostridium spp., the two dominant bacterial species at site D (Sauvain et al. 2013), are not Fe and Mn reducing bacteria. Therefore, the increase in $\mathrm{Me}_{\mathrm{I}}$ at site $\mathrm{D}$ must be driven by specific activities of either Beggiatoa sp. or the endospore-forming bacterium Clostridium spp. One possible bacterial activity that may explain the high $\mathrm{Me}_{\mathrm{I}}$ concentrations at site D is sulfide oxidation by Beggiatoa sp. (Hagen and Nelson 1997) and therefore a decrease in the amount of metals bound to S(II) forming particulate MeS inert complexes (e.g. Zwolsman et al. 1997). More detailed studies are required to better understand the role of these bacteria on metal speciation.

Trace metal speciation in the overlying water

$\mathrm{Cd}_{\mathrm{T}}, \mathrm{Pb}_{\mathrm{T}}$ and $\mathrm{Cu}_{\mathrm{T}}$ concentrations measured in the overlying water varied between 7.4 and 69, 94 and 2,050, and 872 and 4,000 $\mathrm{ng} \mathrm{L}^{-1}$, respectively (Fig. 2c). All $\mathrm{Me}_{\mathrm{T}}$ concentrations were higher than the $\mathrm{Me}_{\mathrm{T}}$ background concentration level measured at the SLH2 station (3.6, 80, and $712 \mathrm{ng} \mathrm{L}^{-1}$ ). The range of $\mathrm{Cd}_{\mathrm{D}}, \mathrm{Pb}_{\mathrm{D}}$ and $\mathrm{Cu}_{\mathrm{D}}$ concentrations was $3.2-8.1,36-224$ and $142-548 \mathrm{ng} \mathrm{L}^{-1}$ (Fig. 2e). These values are comparable to the $\mathrm{Me}_{\mathrm{D}}$ background concentration level $\left(3.3,41\right.$, and $\left.471 \mathrm{ng} \mathrm{L}^{-1}\right)$. Finally, $\mathrm{Cd}_{\mathrm{dyn}}, \mathrm{Pb}_{\mathrm{dyn}}$ and $\mathrm{Cu}_{\mathrm{dyn}}$ concentrations varied between 1.1 and 6.7, 2.1 and 9.9, 10 and $33 \mathrm{ng} \mathrm{L}^{-1}$, respectively (Fig. 2f). These concentrations were found to be higher than the $\mathrm{Me}_{\mathrm{dyn}}$ background concentration level (0.2-0.3, 1.4-1.6, and 0.9-1.1 $\left.\mathrm{ng} \mathrm{L}^{-1}\right)$ monitored in situ with a VIP at station SLH2 (25 m depth). $\mathrm{Me}_{\mathrm{T}}$ and $\mathrm{Me}_{\mathrm{D}}$ concentrations at sites D and I to K, i.e. where the highest $\mathrm{Me}_{\mathrm{I}}$ concentrations were measured, were not higher relative to the other sites (Fig. 2b, c, e). This suggests that the diffusion of dissolved metal from the sediments to the overlying water is negligible, and therefore that the sediments of Vidy Bay act mainly as a sink for trace metals released by the WWTP effluent.
In the overlying water, metal speciation, based on the particulate $\left(\mathrm{Me}_{\text {part }}\right.$ : difference between $\mathrm{Me}_{\mathrm{T}}$ and $\mathrm{Me}_{\mathrm{D}}$ concentrations), colloidal ( $\mathrm{Me}_{\text {coll }}$ : difference between $\mathrm{Me}_{\mathrm{D}}$ and $\mathrm{Me}_{\mathrm{dyn}}$ concentrations) and dynamic fractions, was found to be significantly different, within the analytical errors, from one metal to another at a given site and between the various sites for a given metal (Fig. 3). The proportions of the $\mathrm{Cd}_{\mathrm{dyn}}$ fraction, i.e. the ratio of the $\mathrm{Cd}$ species potentially bioavailable (e.g. Buffle and TercierWaeber 2005) to the total Cd concentration, were found to vary as a function of surface sediment characteristics; i.e. $<10 \%$ in the overlying water of the sediments covered by white filament-like bacteria; $15-30 \%$ at sites with high and low methanogenic activity; $>45 \%$ at sites without bacterial mats and methanogenic activity (Fig. 3). The proportion of the $\mathrm{Cu}$ and $\mathrm{Pb}$ dynamic species was found to be low $(\leq 5 \%)$ at all sites (Fig. 3). These low $\mathrm{Cu}_{\mathrm{dyn}}$ and $\mathrm{Pb}_{\mathrm{dyn}}$ proportions, compared to the $\mathrm{Cd}_{\mathrm{dyn}}$ proportions, are in good agreement with the binding strength of the target metals on natural colloids determined from the ratio of GIME $\mathrm{Me}_{\mathrm{dyn}}$ to $\mathrm{Me}_{\mathrm{D}}$ in freshwater samples stepwise acidified at $\mathrm{pH}$ 8-2 (Buffle and Tercier-Waeber 2005). The proportions of the $\mathrm{Cu}_{\mathrm{dyn}}$ fraction were generally lower in the presence of bacterial mats $(<1 \%)$ than in absence of bacterial mats $(1-4 \%)$. No clear relationship between $\mathrm{Pb}_{\text {dyn }}$ and the surface sediment characteristics was observed. Decreases in both $\mathrm{Cd}_{\mathrm{dyn}}$ and $\mathrm{Cu}_{\mathrm{dyn}}$ suggest that a significant fraction of these metal species is either assimilated by bacterial communities or complexed by their exudates as non-labile or non-mobile species, or both (Tercier-Waeber et al. 2009; Simon et al. 2011). The role of biota is supported by the fact that $\mathrm{Pb}_{\mathrm{dyn}}$, which is known to be not easily assimilated, does not show the same trends. The proportions of the $\mathrm{Cd}_{\text {coll }}$ and $\mathrm{Pb}_{\text {coll }}$ fractions were also different as a function of the surface sediment characteristics; i.e. respectively 0 and $4 \%$ at sites with high methanogenic activity, 2-25 and 10-20\% at sites characterized by bacterial mats, $20-50$ and $35-75 \%$ at sites without bacterial mats and methanogenic activity (Fig. 3). For $\mathrm{Cu}$, no changes in the proportions of colloidal species were observed in the presence or absence of bacterial mats at the sediment surface (Fig. 3). Considering that at the level of metal concentrations measured in the overlying water, $\mathrm{Cd}$ and $\mathrm{Pb}$ are expected to be bound mainly to inorganic colloids (e.g. $\mathrm{Mn}$ and $\mathrm{Fe}$ (hydrous-)oxides) while $\mathrm{Cu}$ is mainly complexed to organic matter (Dong et al. 2007), one hypothesis that may explain the decrease of $\mathrm{Cd}_{\text {coll }}$ and $\mathrm{Pb}_{\text {coll }}$ at the site characterized by bacterial communities is the hetero-aggregation of inorganic colloids resulting from their bridging by extracellular polymeric substances (Tercier-Waeber et al. 2012). More detailed studies coupling trace metal speciation with characterization of colloidal and particulate matter at the 
Table 2 Concentrations of $\mathrm{Cd}, \mathrm{Pb}, \mathrm{Cu}, \mathrm{Fe}$ and $\mathrm{Mn}$ adsorbed in the sediment $\left(\mathrm{Me}_{\mathrm{p}}\right.$; in $\left.\mathrm{mg} \mathrm{kg}^{-1}\right)$ and measured in the interstitial water $\left(\mathrm{Me}_{\mathrm{I}}\right.$; in $\left.\mathrm{ng} \mathrm{L}^{-1}\right)$ for the three sampled layers $(0-1.5,1.5-3,3-6 \mathrm{~cm})$;

\begin{tabular}{|c|c|c|c|c|c|c|}
\hline Sed. int./o.w. & $\begin{array}{l}\mathrm{Cd} \\
\mathrm{mg} \mathrm{kg}^{-1} \\
\mathrm{ng} \mathrm{L}^{-1}\end{array}$ & $\begin{array}{l}\mathrm{Pb} \\
\mathrm{mg} \mathrm{kg}^{-1} \\
\mathrm{ng} \mathrm{L}^{-1}\end{array}$ & $\begin{array}{l}\mathrm{Cu} \\
\mathrm{mg} \mathrm{kg}^{-1} \\
\mathrm{ng} \mathrm{L}^{-1}\end{array}$ & $\begin{array}{l}\mathrm{Fe} \\
\mathrm{g} \mathrm{kg}^{-1} \\
\mu \mathrm{g} \mathrm{L} \mathrm{L}^{-1}\end{array}$ & $\begin{array}{l}\mathrm{Mn} \\
\mathrm{g} \mathrm{kg}^{-1} \\
\mu \mathrm{g} \mathrm{L} \mathrm{L}^{-1}\end{array}$ & POC (\%) \\
\hline \multicolumn{7}{|l|}{ A } \\
\hline $\mathrm{Me}_{\mathrm{P}} 0-1.3 \mathrm{~cm}$ & 1.84 & 120 & 179 & 35.8 & 0.389 & 4.3 \\
\hline $\mathrm{Me}_{\mathrm{P}} 1.5-3 \mathrm{~cm}$ & 1.58 & 101 & 160 & 33.6 & 0.395 & \\
\hline $\mathrm{Me}_{\mathrm{P}} 3-6 \mathrm{~cm}$ & 2.62 & 169 & 218 & 34.4 & 0.425 & 4.5 \\
\hline Average & 2.01 & 130 & 185 & 34.6 & 0.403 & 4.4 \\
\hline $\mathrm{Me}_{\mathrm{I}} 0-1.5 \mathrm{~cm}$ & 7.2 & 45 & 1,190 & 25.6 & 2.59 & \\
\hline $\mathrm{Me}_{\mathrm{I}} 1.5-3 \mathrm{~cm}$ & 6.9 & 182 & 326 & 2,150 & 59.0 & \\
\hline $\mathrm{Me}_{\mathrm{I}} 3-6 \mathrm{~cm}$ & 19 & 623 & 1,660 & 6,990 & 20.7 & \\
\hline Average & 11 & 283 & 1,060 & 3,060 & 27.4 & \\
\hline $\mathrm{Me}_{\mathrm{T}}$ & 43 & 1,520 & 1,890 & 11.3 & 17.5 & \\
\hline $\mathrm{Me}_{\mathrm{D}}$ & 4.6 & 68 & 185 & 9.24 & 13.4 & \\
\hline $\mathrm{Me}_{\mathrm{dyn}}$ & 5.6 & 10 & 26 & & & \\
\hline \multicolumn{7}{|l|}{ B } \\
\hline $\mathrm{Me}_{\mathrm{P}} 0-1.5 \mathrm{~cm}$ & 1.91 & 119 & 203 & 35.5 & 0.378 & 4.5 \\
\hline $\mathrm{Me}_{\mathrm{P}} 1.5-3 \mathrm{~cm}$ & 1.99 & 104 & 192 & 36.7 & 0.403 & \\
\hline $\mathrm{Me}_{\mathrm{P}} 3-6 \mathrm{~cm}$ & 2.06 & 115 & 199 & 35.2 & 0.407 & 3.9 \\
\hline Average & 1.98 & 112 & 198 & 35.8 & 0.396 & 4.2 \\
\hline $\mathrm{Me}_{\mathrm{I}} 0-1.5 \mathrm{~cm}$ & 7.2 & 171 & 536 & 542 & 46.0 & \\
\hline $\mathrm{Me}_{\mathrm{I}} 1.5-3 \mathrm{~cm}$ & 2.9 & 51 & 396 & 436 & 55.0 & \\
\hline $\mathrm{Me}_{\mathrm{I}} 3-6 \mathrm{~cm}$ & 7.3 & 54 & 450 & 1,150 & 74.7 & \\
\hline Average & 5.8 & 92 & 461 & 709 & 58.6 & \\
\hline $\mathrm{Me}_{\mathrm{T}}$ & 32 & 686 & 1,660 & 6.92 & 16.4 & \\
\hline $\mathrm{Me}_{\mathrm{D}}$ & 5.2 & 36 & 204 & 10.2 & 11.0 & \\
\hline $\mathrm{Me}_{\mathrm{dyn}}$ & 6.7 & 6 & 8 & & & \\
\hline \multicolumn{7}{|l|}{$\mathrm{C}$} \\
\hline $\mathrm{Me}_{\mathrm{P}} 0-1.5 \mathrm{~cm}$ & 2.77 & 151 & 182 & 31.1 & 0.349 & 4.4 \\
\hline $\mathrm{Me}_{\mathrm{P}} 1.5-3 \mathrm{~cm}$ & 1.53 & 95.4 & 166 & 32.4 & 0.361 & \\
\hline $\mathrm{Me}_{\mathrm{P}} 3-6 \mathrm{~cm}$ & 1.59 & 97.3 & 177 & 31.7 & 0.374 & 4.2 \\
\hline Average & 1.96 & 115 & 175 & 31.7 & 0.361 & 4.3 \\
\hline $\mathrm{Me}_{\mathrm{I}} 0-1.5 \mathrm{~cm}$ & 5.8 & 186 & 655 & 176 & 35.4 & \\
\hline $\mathrm{Me}_{\mathrm{I}} 1.5-3 \mathrm{~cm}$ & 3.6 & 95 & 261 & 224 & 46.0 & \\
\hline $\mathrm{Me}_{\mathrm{I}} 3-6 \mathrm{~cm}$ & 9.9 & 226 & 1,970 & 2,360 & 73.0 & \\
\hline Average & 6.4 & 169 & 962 & 920 & 51.5 & \\
\hline $\mathrm{Me}_{\mathrm{T}}$ & 21 & 428 & 1,770 & 13.0 & 21.2 & \\
\hline $\mathrm{Me}_{\mathrm{D}}$ & 5.4 & 39 & 142 & 12.3 & 16.6 & \\
\hline $\mathrm{Me}_{\mathrm{dyn}}$ & 6.2 & 6 & 10 & & & \\
\hline \multicolumn{7}{|l|}{$\mathrm{D}$} \\
\hline $\mathrm{Me}_{\mathrm{P}} 0-1.5 \mathrm{~cm}$ & 5.84 & 247 & 258 & 42.9 & 0.345 & 7.0 \\
\hline $\mathrm{Me}_{\mathrm{P}} 1.5-3 \mathrm{~cm}$ & 10.2 & 418 & 333 & 53.4 & 0.367 & \\
\hline $\mathrm{Me}_{\mathrm{P}} 3-6 \mathrm{~cm}$ & 13.2 & 491 & 352 & 52.3 & 0.396 & 7.7 \\
\hline Average & 9.77 & 386 & 314 & 49.5 & 0.369 & 7.4 \\
\hline $\mathrm{Me}_{\mathrm{I}} 0-1.5 \mathrm{~cm}$ & 22.8 & 239 & 1,190 & 252 & 6.71 & \\
\hline $\mathrm{Me}_{\mathrm{I}} 1.5-3 \mathrm{~cm}$ & 149 & 3,050 & 4,610 & 621 & 13.5 & \\
\hline $\mathrm{Me}_{\mathrm{I}} 3-6 \mathrm{~cm}$ & 368 & 9,620 & 6,110 & 732 & 45.3 & \\
\hline Average & 180 & 4,300 & 3,970 & 535 & 21.9 & \\
\hline $\mathrm{Me}_{\mathrm{T}}$ & 69 & 2,050 & 2,680 & 7.99 & 23.7 & \\
\hline $\mathrm{Me}_{\mathrm{D}}$ & 8.0 & 224 & 523 & 21.2 & 15.8 & \\
\hline $\mathrm{Me}_{\mathrm{dyn}}$ & 5.3 & 4 & 10 & & & \\
\hline
\end{tabular}

concentrations of $\mathrm{Cd}, \mathrm{Pb}, \mathrm{Cu}, \mathrm{Fe}$ total $\left(\mathrm{Me}_{\mathrm{T}}\right)$, dissolved $\left(\mathrm{Me}_{\mathrm{D}}\right)$ and dynamic $\left(\mathrm{Me}_{\mathrm{dyn}}\right)$ fractions measured in the overlying water (in $\mathrm{n} \mathrm{L} \mathrm{L}^{-1}$ ); and POC concentrations measured in the sediment 
Table 2 continued

\begin{tabular}{|c|c|c|c|c|c|c|}
\hline Sed. int./o.w. & $\begin{array}{l}\mathrm{Cd} \\
\mathrm{mg} \mathrm{kg}^{-1} \\
\mathrm{ng} \mathrm{L}^{-1}\end{array}$ & $\begin{array}{l}\mathrm{Pb} \\
\mathrm{mg} \mathrm{kg}^{-1} \\
\mathrm{ng} \mathrm{L}^{-1}\end{array}$ & $\begin{array}{l}\mathrm{Cu} \\
\mathrm{mg} \mathrm{kg}^{-1} \\
\mathrm{ng} \mathrm{L}^{-1}\end{array}$ & $\begin{array}{l}\mathrm{Fe} \\
\mathrm{g} \mathrm{kg}^{-1} \\
\mu \mathrm{g} \mathrm{L}^{-1}\end{array}$ & $\begin{array}{l}\mathrm{Mn} \\
\mathrm{g} \mathrm{kg}^{-1} \\
\mu \mathrm{g} \mathrm{L}^{-1}\end{array}$ & POC (\%) \\
\hline \multicolumn{7}{|l|}{$\mathrm{E}$} \\
\hline $\mathrm{Me}_{\mathrm{P}} 0-1.5 \mathrm{~cm}$ & 0.990 & 58.8 & 107 & 29.6 & 0.394 & \\
\hline $\mathrm{Me}_{\mathrm{P}} 1.5-3 \mathrm{~cm}$ & 0.980 & 56.5 & 117 & 31.1 & 0.415 & 4.1 \\
\hline $\mathrm{Me}_{\mathrm{P}} 3-6 \mathrm{~cm}$ & 0.859 & 48.3 & 92.8 & 32.2 & 0.475 & 3.3 \\
\hline Average & 0.943 & 54.5 & 106 & 31.0 & 0.428 & 3.7 \\
\hline $\mathrm{Me}_{\mathrm{I}} 0-1.5 \mathrm{~cm}$ & 3.6 & 264 & 374 & 62.5 & 52.3 & \\
\hline $\mathrm{Me}_{\mathrm{I}} 1.5-3 \mathrm{~cm}$ & 4.9 & 428 & 779 & 211 & 55.2 & \\
\hline $\mathrm{Me}_{\mathrm{I}} 3-6 \mathrm{~cm}$ & 13 & 666 & 1,700 & 635 & 47.3 & \\
\hline Average & 7.0 & 453 & 951 & 303 & 51.6 & \\
\hline $\mathrm{Me}_{\mathrm{T}}$ & 7.7 & 161 & 941 & 8.77 & 15.6 & \\
\hline $\mathrm{Me}_{\mathrm{D}}$ & 6.5 & 125 & 237 & 10.8 & 11.4 & \\
\hline $\mathrm{Me}_{\mathrm{dyn}}$ & 5.1 & 6 & 16 & & & \\
\hline \multicolumn{7}{|l|}{$\mathrm{F}$} \\
\hline $\mathrm{Me}_{\mathrm{P}} 0-1.5 \mathrm{~cm}$ & 1.37 & 85.7 & 151 & 31.2 & 0.399 & 4.0 \\
\hline $\mathrm{Me}_{\mathrm{P}} 1.5-3 \mathrm{~cm}$ & 1.31 & 85.0 & 148 & 31.3 & 0.377 & \\
\hline $\mathrm{Me}_{\mathrm{P}} 3-6 \mathrm{~cm}$ & 2.22 & 141 & 205 & 32.2 & 0.378 & 5.1 \\
\hline Average & 1.63 & 104 & 168 & 31.5 & 0.385 & 4.5 \\
\hline $\mathrm{Me}_{\mathrm{I}} 0-1.5 \mathrm{~cm}$ & 11 & 125 & 356 & 266 & 27.3 & \\
\hline $\mathrm{Me}_{\mathrm{I}} 1.5-3 \mathrm{~cm}$ & 7.2 & 54 & 630 & 443 & 28.5 & \\
\hline $\mathrm{Me}_{\mathrm{I}} 3-6 \mathrm{~cm}$ & 14 & 60 & 1,430 & 644 & 55.3 & \\
\hline Average & 11 & 80 & 805 & 451 & 37.0 & \\
\hline $\mathrm{Me}_{\mathrm{T}}$ & 22 & 311 & 1,340 & 11.3 & 15.0 & \\
\hline $\mathrm{Me}_{\mathrm{D}}$ & 6.5 & 176 & 426 & 11.1 & 9.08 & \\
\hline $\mathrm{Me}_{\mathrm{dyn}}$ & 3.8 & 4 & 27 & & & \\
\hline \multicolumn{7}{|l|}{ G } \\
\hline $\mathrm{Me}_{\mathrm{P}} 0-1.5 \mathrm{~cm}$ & 1.00 & 58.4 & 133 & 31.0 & 0.411 & 3.7 \\
\hline $\mathrm{Me}_{\mathrm{P}} 1.5-3 \mathrm{~cm}$ & 1.04 & 64.2 & 130 & 31.0 & 0.405 & \\
\hline $\mathrm{Me}_{\mathrm{P}} 3-6 \mathrm{~cm}$ & 1.13 & 67.3 & 127 & 31.4 & 0.405 & 3.6 \\
\hline Average & 1.06 & 63.3 & 130 & 31.1 & 0.407 & 3.7 \\
\hline $\mathrm{Me}_{\mathrm{I}} 0-1.5 \mathrm{~cm}$ & 6.4 & 149 & 662 & 174 & 42.4 & \\
\hline $\mathrm{Me}_{\mathrm{I}} 1.5-3 \mathrm{~cm}$ & 5.9 & 207 & 823 & 206 & 9.42 & \\
\hline $\mathrm{Me}_{\mathrm{I}} 3-6 \mathrm{~cm}$ & 23 & 669 & 2,250 & 916 & 31.9 & \\
\hline Average & 12 & 341 & 1,240 & 432 & 27.9 & \\
\hline $\mathrm{Me}_{\mathrm{T}}$ & 16 & 94 & 1,300 & 25.1 & 22.1 & \\
\hline $\mathrm{Me}_{\mathrm{D}}$ & 5.3 & 65 & 166 & 7.01 & 17.5 & \\
\hline $\mathrm{Me}_{\mathrm{dyn}}$ & 2.1 & 5 & 27 & & & \\
\hline \multicolumn{7}{|l|}{$\mathrm{H}$} \\
\hline $\mathrm{Me}_{\mathrm{P}} 0-1.5 \mathrm{~cm}$ & 0.940 & 47.6 & 93.0 & 31.0 & 0.441 & 3.3 \\
\hline $\mathrm{Me}_{\mathrm{P}} 1.5-3 \mathrm{~cm}$ & 0.998 & 51.9 & 106 & 34.1 & 0.486 & \\
\hline $\mathrm{Me}_{\mathrm{P}} 3-6 \mathrm{~cm}$ & 1.04 & 64.0 & 130 & 29.8 & 0.390 & 2.9 \\
\hline Average & 0.99 & 54.5 & 110 & 31.7 & 0.439 & 3.1 \\
\hline $\mathrm{Me}_{\mathrm{I}} 0-1.5 \mathrm{~cm}$ & 5.4 & 151 & 1,160 & 532 & 67.8 & \\
\hline $\mathrm{Me}_{\mathrm{I}} 1.5-3 \mathrm{~cm}$ & 2.8 & 62 & 584 & 1,040 & 96.1 & \\
\hline $\mathrm{Me}_{\mathrm{I}} 3-6 \mathrm{~cm}$ & 11 & 375 & 2,390 & 1,510 & 123 & \\
\hline Average & 6.3 & 196 & 1,380 & 1,030 & 95.7 & \\
\hline $\mathrm{Me}_{\mathrm{T}}$ & 7.4 & 150 & 872 & 7.33 & 21.4 & \\
\hline $\mathrm{Me}_{\mathrm{D}}$ & 8.1 & 70 & 264 & 7.38 & 16.2 & \\
\hline $\mathrm{Me}_{\mathrm{dyn}}$ & 4.1 & 7 & 31 & & & \\
\hline
\end{tabular}


Table 2 continued

\begin{tabular}{|c|c|c|c|c|c|c|}
\hline Sed. int./o.w. & $\begin{array}{l}\mathrm{Cd} \\
\mathrm{mg} \mathrm{kg}^{-1} \\
\mathrm{ng} \mathrm{L}^{-1}\end{array}$ & $\begin{array}{l}\mathrm{Pb} \\
\mathrm{mg} \mathrm{kg}^{-1} \\
\mathrm{ng} \mathrm{L}^{-1}\end{array}$ & $\begin{array}{l}\mathrm{Cu} \\
\mathrm{mg} \mathrm{kg}^{-1} \\
\mathrm{ng} \mathrm{L}^{-1}\end{array}$ & $\begin{array}{l}\mathrm{Fe} \\
\mathrm{g} \mathrm{kg}^{-1} \\
\mu \mathrm{g} \mathrm{L}^{-1}\end{array}$ & $\begin{array}{l}\mathrm{Mn} \\
\mathrm{g} \mathrm{kg}^{-1} \\
\mu \mathrm{g} \mathrm{L}^{-1}\end{array}$ & POC $(\%)$ \\
\hline \multicolumn{7}{|l|}{ I } \\
\hline $\mathrm{Me}_{\mathrm{P}} 0-1.5 \mathrm{~cm}$ & 1.31 & 98.3 & 205 & 40.2 & 0.334 & 12.6 \\
\hline $\mathrm{Me}_{\mathrm{P}} 1.5-3 \mathrm{~cm}$ & 1.36 & 53.3 & 219 & 51.2 & 0.348 & 13.2 \\
\hline $\mathrm{Me}_{\mathrm{P}} 3-6 \mathrm{~cm}$ & 1.33 & 49.6 & 253 & 64.4 & 0.324 & 10.1 \\
\hline Average & 1.33 & 67.1 & 226 & 51.9 & 0.335 & 12.0 \\
\hline $\mathrm{Me}_{\mathrm{I}} 0-1.5 \mathrm{~cm}$ & 28 & 886 & 8,850 & 5,870 & 78.3 & \\
\hline $\mathrm{Me}_{\mathrm{I}} 1.5-3 \mathrm{~cm}$ & 50 & 1,350 & 15,800 & 2,700 & 55.8 & \\
\hline $\mathrm{Me}_{\mathrm{I}} 3-6 \mathrm{~cm}$ & 43 & 1,060 & 13,800 & 10,300 & 117 & \\
\hline Average & 40 & 1,100 & 12,800 & 6,290 & 83.6 & \\
\hline $\mathrm{Me}_{\mathrm{T}}$ & 20 & 734 & 4,000 & 820 & 8.40 & \\
\hline $\mathrm{Me}_{\mathrm{D}}$ & 4.0 & 104 & 390 & 45.7 & 6.31 & \\
\hline $\mathrm{Me}_{\mathrm{dyn}}$ & 4.2 & 7 & 24 & & & \\
\hline \multicolumn{7}{|l|}{$\mathrm{J}$} \\
\hline $\mathrm{Me}_{\mathrm{P}} 0-1.5 \mathrm{~cm}$ & 1.23 & 54.4 & 161 & 39.3 & 0.388 & 4.7 \\
\hline $\mathrm{Me}_{\mathrm{P}} 1.5-3 \mathrm{~cm}$ & 1.21 & 59.0 & 139 & 39.4 & 0.403 & 4.7 \\
\hline $\mathrm{Me}_{\mathrm{P}} 3-6 \mathrm{~cm}$ & 1.33 & 61.0 & 164 & 47.1 & 0.379 & 4.3 \\
\hline Average & 1.26 & 58.13 & 154 & 42.0 & 0.390 & 4.6 \\
\hline $\mathrm{Me}_{\mathrm{I}} 0-1.5 \mathrm{~cm}$ & 22 & 695 & 5,310 & 3,930 & 80.8 & \\
\hline $\mathrm{Me}_{\mathrm{I}} 1.5-3 \mathrm{~cm}$ & 36 & 1,330 & 6,160 & 3,740 & 97.0 & \\
\hline $\mathrm{Me}_{\mathrm{I}} 3-6 \mathrm{~cm}$ & 60 & 2,030 & 11,900 & 8,110 & 183 & \\
\hline Average & 39 & 1,350 & 7,790 & 5,260 & 120 & \\
\hline $\mathrm{Me}_{\mathrm{T}}$ & 33 & 1,170 & 2,980 & 546 & 6.71 & \\
\hline $\mathrm{Me}_{\mathrm{D}}$ & 3.5 & 96 & 354 & 19.1 & 4.92 & \\
\hline $\mathrm{Me}_{\mathrm{dyn}}$ & 2.7 & 3 & 22 & & & \\
\hline \multicolumn{7}{|l|}{$\mathrm{K}$} \\
\hline $\mathrm{Me}_{\mathrm{P}} 0-1.5 \mathrm{~cm}$ & 1.27 & 48.9 & 179 & 42.6 & 0.367 & 4.3 \\
\hline $\mathrm{Me}_{\mathrm{P}} 1.5-3 \mathrm{~cm}$ & 1.19 & 53.8 & 145 & 39.2 & 0.412 & 4.4 \\
\hline $\mathrm{Me}_{\mathrm{P}} 3-6 \mathrm{~cm}$ & 1.36 & 61.5 & 158 & 49.5 & 0.421 & 4.0 \\
\hline Average & 1.27 & 54.7 & 161 & 43.7 & 0.400 & 4.2 \\
\hline $\mathrm{Me}_{\mathrm{I}} 0-1.5 \mathrm{~cm}$ & 29 & 935 & 6,080 & 1,680 & 38.7 & \\
\hline $\mathrm{Me}_{\mathrm{I}} 1.5-3 \mathrm{~cm}$ & 54 & 1,550 & 9,550 & 1,580 & 59.3 & \\
\hline $\mathrm{Me}_{\mathrm{I}} 3-6 \mathrm{~cm}$ & 128 & 3,160 & 21,000 & 5,030 & 112 & \\
\hline Average & 71 & 1,880 & 12,200 & 2,760 & 69.9 & \\
\hline $\mathrm{Me}_{\mathrm{T}}$ & 13 & 414 & 1,500 & 166 & 3.00 & \\
\hline $\mathrm{Me}_{\mathrm{D}}$ & 4.2 & 88 & 548 & 18.6 & 1.29 & \\
\hline $\mathrm{Me}_{\mathrm{dyn}}$ & 1.1 & 2 & 33 & & & \\
\hline \multicolumn{7}{|l|}{$\mathrm{L}$} \\
\hline $\mathrm{Me}_{\mathrm{P}} 0-1.5 \mathrm{~cm}$ & 1.92 & 83.1 & 120 & 26.4 & 0.381 & 4.0 \\
\hline $\mathrm{Me}_{\mathrm{P}} 1.5-3 \mathrm{~cm}$ & 1.70 & 84.9 & 116 & 28.9 & 0.399 & 4.8 \\
\hline $\mathrm{Me}_{\mathrm{P}} 3-6 \mathrm{~cm}$ & 2.30 & 122 & 134 & 31.4 & 0.410 & 4.0 \\
\hline Average & 1.97 & 96.8 & 123 & 28.9 & 0.397 & 4.2 \\
\hline $\mathrm{Me}_{\mathrm{I}} 0-1.5 \mathrm{~cm}$ & 10 & 353 & 1,010 & 231 & 32.0 & \\
\hline $\mathrm{Me}_{\mathrm{I}} 1.5-3 \mathrm{~cm}$ & 10 & 315 & 765 & 192 & 33.6 & \\
\hline $\mathrm{Me}_{\mathrm{I}} 3-6 \mathrm{~cm}$ & 41 & 1,770 & 2,910 & 1,960 & 68.5 & \\
\hline Average & 21 & 813 & 1,560 & 794 & 44.7 & \\
\hline $\mathrm{Me}_{\mathrm{T}}$ & 9.0 & 327 & 875 & 63.3 & 1.93 & \\
\hline $\mathrm{Me}_{\mathrm{D}}$ & 5.4 & 116 & 491 & 17.0 & 1.25 & \\
\hline $\mathrm{Me}_{\mathrm{dyn}}$ & 4.3 & 3 & 29 & & & \\
\hline
\end{tabular}



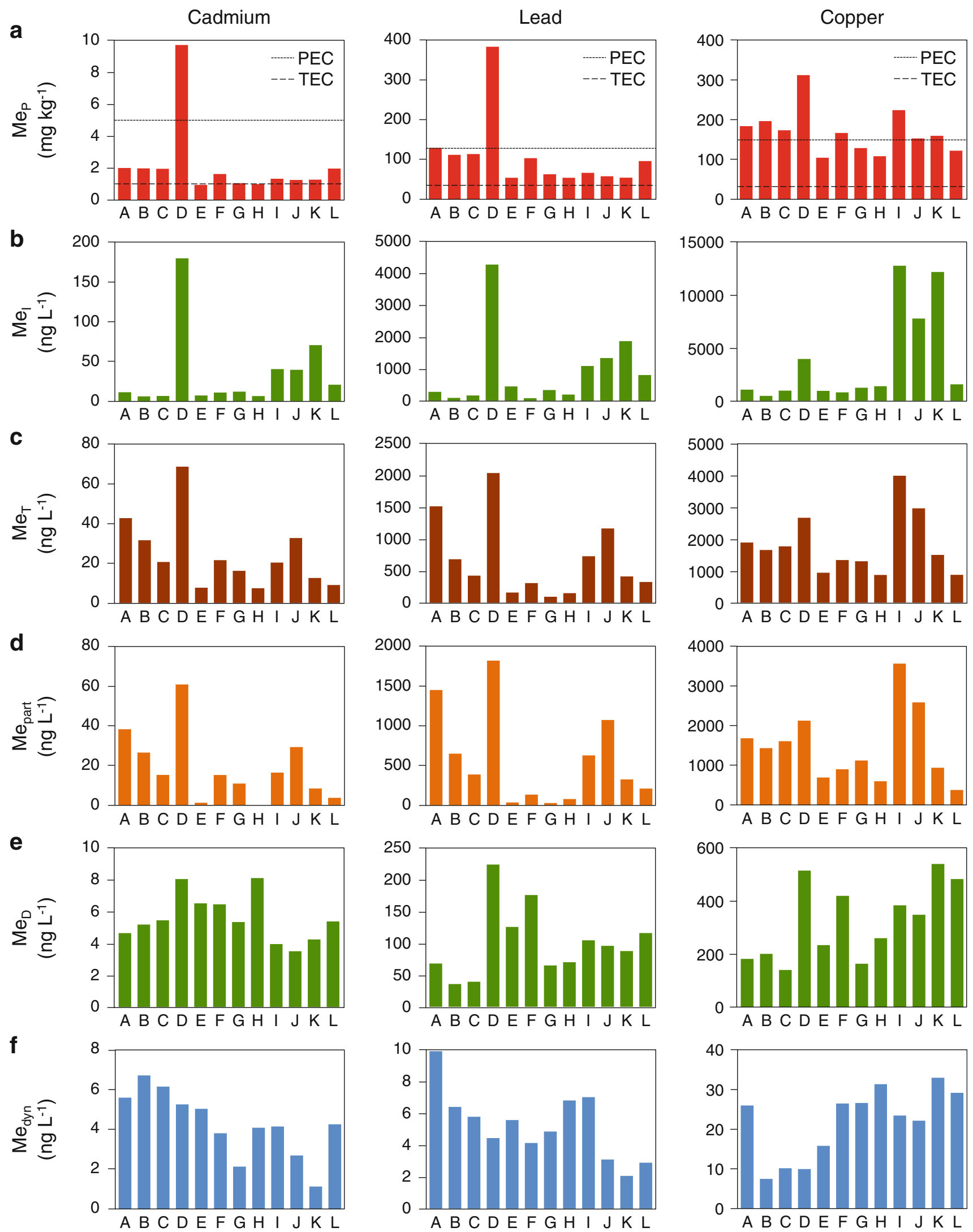
4 Fig. 2 Mean $\mathrm{Cd}, \mathrm{Pb}$ and $\mathrm{Cu}$ concentrations determined from concentrations measured in the three layers $(0-1.5,1.5-3,3-6 \mathrm{~cm})$ of the sediment $\left(\mathbf{a} \mathrm{Me}_{\mathrm{P}}\right)$ and of the overlying water $\left(\mathbf{b} \mathrm{Me}_{\mathrm{I}}\right)$. Concentrations of the $\mathrm{Cd}, \mathrm{Pb}$ and $\mathrm{Cu}$ total $\left(\mathbf{c} \mathrm{Me}_{\mathrm{T}}\right)$, particulate $\left(\mathbf{d} \mathrm{Me}_{\mathrm{part}}\right)$, total dissolved $\left(\mathbf{e} \mathrm{Me}_{\mathrm{D}}\right)$ and dynamic $\left(\mathbf{f} \mathrm{Me}_{\mathrm{dyn}}\right)$ fractions measured in the overlying water

various sites are required to verify this hypothesis. Finally, the $\mathrm{Me}_{\text {part }}$ proportions of the three metals were generally higher at all sites characterized by methanogenic activity (Fig. 3). This may be explained by a resuspension of $\mathrm{Me}_{\mathrm{P}}$ in the overlying water due to intense methane degassing. The increase in suspended particulate matter, favoring the adsorption/aggregation of colloidal metal species, may also explain the low contributions of $\mathrm{Cd}_{\text {coll }}$ and $\mathrm{Pb}_{\text {coll }}$ at these sites (Fig. 3).

\section{Summary and outlook}

For the first time, speciation of $\mathrm{Cd}, \mathrm{Pb}$ and $\mathrm{Cu}$ in addition to total metal concentrations were investigated at the sediment-water interface of Vidy Bay. This work was a first attempt to evaluate the potential impact of contrasting sediment characteristics on trace metal speciation in both compartments. Several interesting findings were obtained: (1) the study confirmed that the elongation of the outlet pipe releasing WWTP sewage effluent has not solved the problem of contamination of sediments by trace metals not retained during water treatment. (2) The differences in trace metal concentrations and speciation at the sedimentwater interface were found to be more related to sediment bacterial abundance, activity and types than to the distance from the outlet pipe. (3) Bacterial activity was found to influence the speciation of the three metals in the sediment and overlying water via processes that depend on the abundance and type of bacterial community. Increase in dissolved metal concentrations in the interstitial water $\left(\mathrm{Me}_{\mathrm{I}}\right)$ was attributed to organic matter mineralization, $\mathrm{Fe} /$ $\mathrm{Mn}$ oxide reduction and sulfide oxidation. Methanogenic activity induces resuspension of metal in particulate form $\left(\mathrm{Me}_{\mathrm{P}}\right)$ from the sediment to the overlying water. Bacterial activity is also suspected to be at the origin of the changes in the proportion of dynamic $\left(\mathrm{Me}_{\mathrm{dyn}}\right)$ and colloidal $\left(\mathrm{Me}_{\mathrm{coll}}\right)$ metal species in the overlying water. (4) Finally, the results of this study suggest that the sediments act mainly as a sink for the metals released by the WWTP effluent; the only identified exception being related to the $\mathrm{Me}_{\mathrm{P}}$ resuspension induced by methane degassing. Findings $2-4$ could not be obtained from measurements of only metal in the particulate form in the sediments as performed in the previous studies. They highlight the interest and potential of the proposed analytical approach coupling visual observation of sediment characteristics with combined in situ and laboratory measurements of metal concentrations and speciation in the different compartments (i.e. sediment, interstitial and overlying waters) to study the behavior and fate of trace metals at the sediment-water interface and identify the processes that may control them.

More detailed spatial and temporal studies coupling high-resolution chemical measurements (trace metal speciation, redox compounds, major ion concentrations, colloidal and particulate matter characterization) to microbiological characterization are still needed. This is a pre-requisite condition to investigate in depth the feedback interactions between trace metal speciation and bacterial community, and the way for more reliable evaluation of the behavior and fate of trace metals released by the WWTP effluent, and assessment of their long-term impact on the Vidy Bay ecosystem.
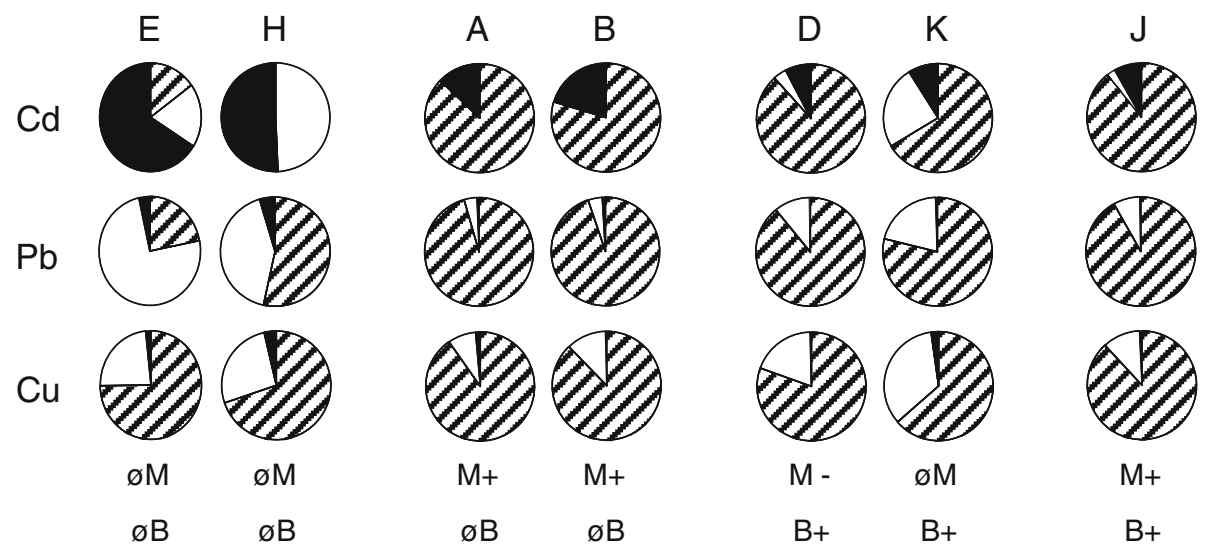

Fig. 3 Proportion of the $\mathrm{Cd}, \mathrm{Pb}$ and $\mathrm{Cu}$ particulate (hatched area), colloidal (white area) and dynamic (black area) fractions to the total metal concentration measured in the overlying water at selected sites characterized by absence of methanogenic activity and bacterial mat

(sites $E, H$ ), high methanogenic activity and absence of bacterial mat (sites $A, B$ ), absence or low methanogenic activity and presence of large bacterial mat (sites $D, K$ ), and high methanogenic activity and presence of large bacterial mat (site $J$ ) 
Acknowledgments This publication is part of the international, interdisciplinary research project éLEMO (http://www.elemo.ch) to investigate the deep-waters of Lake Geneva using two Russian MIR submarines. Funding for this study was provided by the Fondation pour l'Etude des Eaux du Léman (FEEL). We are grateful for the support. We thank the Russian MIR crew members (www.elemo.ch/ mir-team) for their excellent performance and the SAGRAVE team who provided and operated the platform from which the dives were carried out. We also thank Ulrich Lemmin and Jean-Denis Bourquin for éLEMO project coordination and Jean-Luc Loizeau for dive planning. The service of Mikhail Kranoperov (Russian Honorary Consulate) as liaison is greatly appreciated. The authors acknowledge Elena Gascón-Diez, Loïc Sauvin and Neil Graham for sampling assistance and Matthieu Bueche for sampling assistance and POC analysis.

\section{References}

Arbouille D, Howa H, Soan D, Vernet J (1989) Etude générale de la pollution par les métaux et repartition des nutriments dans les sédiments du Léman. Rapport Commission Internationale pour la Protection des Eaux du Léman, Campagne 2008 105:139-172

Bonvin F, Rutler R, Chèvre N, Halder J, Kohn T (2011) Spatial and temporal presence of a wastewater-derived micropollutant plume in Lake Geneva. Environ Sci Technol 45:4702-4709

Buffle J, Tercier-Waeber M-L (2005) Voltammetric environmental trace metal analysis and speciation. From laboratory to in situ measurements. Trends Anal Chem 24:172-191

Dong D, Liu L, Hua X, Lu Y (2007) Comparison of lead, cadmium, copper and cobalt adsorption onto metal oxides and organic materials in natural surface coatings. Microchem J 85:270-275

Froelich PN, Klinkhammer GP, Bender ML, Luedtke NA, Heath GR, Cullen D, Dauphin P, Hammond D, Hartman B, Maynard V (1979) Early diagenesis of organic matter in pelagic sediments of the eastern equatorial Atlantic: suboxic diagenesis. Geochim Cosmochim Acta 43:1075-1090

Goldscheider N, Haller L, Poté J, Wildi W, Zopfi J (2007) Characterizing water circulation and contaminant transport in Lake Geneva using bacteriophage tracer experiments and limnological methods. Environ Sci Technol 41:5252-5258

Hagen KD, Nelson DC (1997) Use of reduced sulfur compounds by Beggiatoa spp.: enzymology and physiology of marine and freshwater strains in homogeneous and gradient cultures. Appl Environ Microbiol 63(10):3957-3964

Haller L, Tonolla M, Zopfi J, Peduzzi R, Wildi W, Poté J (2011) Composition of bacterial and archaeal communities in freshwater sediments with different contamination levels (Lake Geneva, Switzerland). Water Res 45:1213-1228

Harris D, Horwath WR, van Fessel C (2001) Acid fumigation of soils to remove carbonates prior to total organic carbon or carbon-13 isotopic analysis. Soil Sci Soc Am J 65(6):1853-1856

Loizeau J-L, Rozé S, Peytremann C, Monna F, Dominik J (2003) Mapping sediment accumulation rate by using volume magnetic susceptibility core correlation in a contaminated bay (Lake Geneva, Switzerland). Eclogae Geol Helv 96:S73-S79

Loizeau J-L, Pardos M, Monna F, Peytremann C, Haller L, Dominik J (2004) The impact of a sewage treatment plant's effluent on sediment quality in a small bay in Lake Geneva (SwitzerlandFrance). Part 2: temporal evolution of heavy metals. Lakes Reserv Res Manag 9:53-63
MacDonald D, Ingersoll C, Berger T (2000) Development and evaluation of consensus-based sediment quality guidelines for freshwater ecosystems. Arch Environ Contam Toxicol 39:20-31

Masson M, Tercier-Waeber M-L, Loizeau J-L, Arpagaus P (in preparation) High resolution spatial and temporal monitoring of the spreading of an anthropogenic effluent and trace metals it contains. Sci Total Environ

Monna F, Dominik J, Loizeau J-L, Pardos M, Arpagaus P (1999) Origin and evolution of $\mathrm{Pb}$ in sediments of Lake Geneva (Switzerland-France). Environ Sci Technol 33:2850-2857

Pardos M, Benninghoff C, Alencastro LP, Wildi W (2004) The impact of a sewage treatment plant's effluent on sediment quality in a small bay in Lake Geneva (Switzerland-France). Part 1: spatial distribution of contaminants and the potential for biological impacts. Lakes Reserv Res Manag 9:41-52

Poté J, Haller L, Loizeau J-L, Garcia Bravo A, Sastre V, Wildi W (2008) Effects of a sewage treatment plant outlet pipe extension on the distribution of contaminants in the sediments of the Bay of Vidy, Lake Geneva, Switzerland. Bioresour Technol 99:7122-7131

Sauvain L, Bueche M, Junier T, Masson M, Wunderlin T, KohlerMilleret R, Gascon Diez E, Loizeau JL, Tercier-Waeber ML, Junier P (2013) Bacterial communities in trace metal contaminated lake sediments are dominated by endospore-forming bacteria. Aquat Sci

Simon DF, Davis TA, Tercier-Waeber M-L, Wilkinson KJ (2011) In situ evaluation of $\mathrm{Cd}$ biomarkers in green algae. Environ Pollut 159:2630-2636

Tercier-Waeber M-L, Taillefert M (2008) Remote in situ voltammetric techniques to characterize the biogeochemical cycling of trace metals in aquatic systems. J Environ Monit 10:30-54

Tercier-Waeber M-L, Hezard T, Masson M, Schäfer J (2009) In situ monitoring of the diurnal cycling of dynamic metal species in a stream under contrasting photobenthic biofilm activity and hydrological conditions. Environ Sci Technol 43:7237-7244

Tercier-Waeber M-L, Stoll S, Slaveykova VI (2012) Trace metal behavior in surface waters: emphasis on dynamic speciation, sorption processes and bioavailability. Arch Sci J 65:119-142

Tercier-Waeber M-L, Masson M, Loizeau J-L, Sénéclauze M, Dallemagne P, Restrepo A, Dussud L, Rousseaux P, Prigent S, Forest B (in preparation) Mobile wireless sensor network: application to 3D tracking of anthropogenic effluent and trace metal it may contains. J Environ Monit

Thevenon F, Graham ND, Chiaradia M, Arpagaus P, Wildi W, Poté J (2011) Local to regional scale industrial heavy metal pollution recorded in sediments of large freshwater lakes in central Europe (Lakes Geneva and Lucerne) over the last centuries. Sci Total Environ 412-413:239-247

Van Den Berg GA, Loch JPG, Van Der Heijdt LM, Zwolsman JJG (1999) Mobilisation of heavy metals in contaminated sediments in the river Meuse, The Netherlands. Water Air Soil Pollut 166:567-586

Wüest A, Anselmetti FS, Arey JS, Ibelings BW, Loizeau JL, Vennemann T, Lemmin U (2013) Into the abyss of Lake Geneva-interdisciplinary field investigations using the MIR submersibles. Aquat Sci

Zwolsman JJG, Van Eck BTM, Van Der Weijden CD (1997) Geochemistry of dissolved trace metals (cadmium, copper, zinc) in the Scheldt estuary, southwestern Netherlands: impact of seasonal variability. Geochim Cosmochim Acta 61:1635-1652 